\title{
No mutations in the coding region of the Rett syndrome gene MECP2 in 59 autistic patients
}

\author{
Patrick Vourc' $\mathrm{h}^{1}$, Thierry Bienvenu ${ }^{2}$, Cherif Beldjord ${ }^{2}$, Jamel Chelly ${ }^{2}$, \\ Catherine Barthélémy ${ }^{3}$, Jean Pierre Müh ${ }^{1}$ and Christian Andres ${ }^{*, 1}$
}

\author{
${ }^{1}$ Laboratoire de Biochimie et Biologie Moléculaire, INSERM U 316, 2 bis Bd Tonnellé, 37032 Tours Cedex, France; \\ ${ }^{2}$ Laboratoire de Génétique et Physiopathologie des retards mentaux- ICGM, Faculté de Médecine Cochin, 24 rue du \\ Faubourg Saint Jacques, 75014 Paris, France; ${ }^{3}$ Service Universitaire d'Explorations Fonctionnelles et \\ Neurophysiologie en Pédopsychiatrie, INSERM U 316, Hôpital Bretonneau, 37032 Tours Cedex, France
}

Autistic disorder is a pervasive developmental disorder considered to have a multigenic origin. Mental retardation is present in $75 \%$ of autistic patients. Autistic features are found in Rett syndrome, a neurological disorder affecting girls and associated with severe mental retardation. Recently, the gene responsible for the Rett syndrome, methyl CpG-binding protein (MECP2) gene, was identified on the $\mathrm{X}$ chromosome by a candidate gene strategy. Mutations in this gene were also observed in some mentally retarded males. In this study we tested MECP2 as a candidate gene in autistic disorder by a DGGE analysis of its coding region and intron-exon boundaries. Among 59 autistic patients, 42 males and 17 females, mentally retarded or not, no mutations or polymorphisms were present in the MECP2 gene. Taking into account the size of our sample, we conclude that MECP2 coding sequence mutations are not an important factor (less than $5 \%$ of cases) in the aetiology of autistic disorder. European Journal of Human Genetics (2001) 9, 556-558.

Keywords: autism; Rett syndrome; MECP2 gene; DGGE analysis

\section{Introduction}

Autistic disorder is a pervasive developmental disorder of unknown aetiology which affects males more often than females. Epidemiological studies suggest a multigenic origin. ${ }^{1}$ However, at this time, no genes have been identified which are clearly associated to autism.

Rett syndrome is another pervasive developmental disorder which affects mainly females with a much lower prevalence than autism. ${ }^{2}$ Some Rett patients present autistic features. ${ }^{3}$ Recently mutations in the MECP2 gene have been identified as being responsible for more than $70 \%$ of Rett syndrome cases. ${ }^{4-6}$ The MECP2 gene encodes a methyl CpGbinding protein. ${ }^{7}$ Moreover, a MECP2 gene mutation has been discovered in one family with recessive X-linked mental retardation with progressive spasticity. ${ }^{8}$ Systematic screening

*Correspondence: Pr Christian Andres, INSERM U 316, Faculté de Médecine de Tours, 2 bis bd Tonnellé, 37032 Tours Cedex, France. Tel: +33 2473661 48; Fax: +33 2473661 52;

Email: andres@med.univ-tours.fr

Received 5 February 2001; revised 28 March 2001; accepted 3 April 2001 of males with sporadic mental retardation negative for FRAXA CGG expansion showed rare MECP2 mutations (T Bienvenu, C Beldjord, J Chelly, personal communication). These observations raise the possibility that MECP2 mutations might be involved in other developmental disorders with mental retardation, like autism. To test this hypothesis, we have screened the coding sequence of the MECP2 gene in 59 sporadic autistic patients.

Materials and methods

Subjects

The autistic patients were 17 females and 42 unrelated males, aged from 4 to 20 years at the time of examination. The DSM IV criteria were used by a team of practicioners to ascertain the diagnosis of autistic disorder. ${ }^{9}$ Recognisable genetic diseases have been excluded by clinics and cytogenetics. The FRAXA mutation at the CGG repeat was excluded by classical PCR technique and Southern analysis. ${ }^{10,11}$ The mean of the developmental quotient (DQ) was 36 (range 12-109), with 44 severe mental retardation $(\mathrm{DQ}<50), 12$ mild mental 
retardation $(50 \leqslant \mathrm{DQ}<70)$ and three normal DQ. We have used the denaturing gradient gel electrophoresis (DGGE) assay to screen the MECP2 gene.

\section{Mutation analysis}

Genomic DNA was extracted from peripheral blood using standard methods. The three exons and the flanking intronic sequences of the MECP2 gene were separately amplified by nine different polymerase chain reactions (PCR) using primers with psoralen clamps. PCR were performed in a total volume of $25 \mu \mathrm{l}$ containing $100 \mathrm{ng}$ of genomic DNA, $1 \times$ GibcoBRL PCR Buffer, $\mathrm{MgCl}_{2} 1.5 \mathrm{mM}, 250 \mu \mathrm{M}$ of each dNTP, 20 pmol of each primer (Table 1) and $0.5 \mathrm{U}$ of Taq DNA polymerase Platinium (GibcoBRL). Amplifications were carried out for $30 \mathrm{~s}$ at $95^{\circ} \mathrm{C}, 30 \mathrm{~s}$ at Tm (see Table 1) and $30 \mathrm{~s}$ at $72^{\circ} \mathrm{C}$ for 40 cycles. Heteroduplex formation consisted of incubation for $5 \mathrm{~min}$ at $94^{\circ} \mathrm{C}$ and $30 \mathrm{~min}$ at $56^{\circ} \mathrm{C}$. For DGGE, gels were run at $60^{\circ} \mathrm{C}$ and the denaturing solution contained $40 \%$ formamide and $7 \mathrm{~m}$ urea. The conditions of electrophoresis are summarised in Table 1.

\section{Results}

No abnormal pattern of migration could be detected. So we did not observe mutations in the MECP2 coding sequence in 59 autistic patients. The polymorphisms described in some Rett syndrome patients were absent in the autistic population tested.

\section{Discussion}

MECP2 gene could be involved in several disorders with mental retardation and not only in Rett syndrome. This hypothesis was confirmed by the observation of mutations in
MECP2 gene in males with mental retardation. Here we tested for the participation of the MECP2 gene in autistic disorder. We used a DGGE analysis by overlapping primer sets encompassing the complete coding region. DGGE is one of the most sensitive methods for screening mutation. ${ }^{12}$ However, no current analytical methods including sequence analysis and DHPLC, have $100 \%$ sensitivity. ${ }^{13}$ The MECP2 gene contains two introns. Mutations in the intron-exon boundaries could produce alternative splicing events. In order to screen these regions, we localised the primer sequences in the introns at 9 to $111 \mathrm{bp}$ of the exon-intron junctions.

No abnormal migration pattern of the PCR products was detected in any of our autistic patients, mentally retarded or not. This observation rules out the possibility that the MECP2 gene is mutated in a significant fraction of autistic patients. Taking into account the size of our sample (59), the percentage of mutations in the autistic population can be estimated to be lower than 5\% (binomial distribution, $n=59$ with $P<0.05$ ). However, as our sample contained only 17 females, we cannot exclude that the MECP2 gene is more frequently mutated in a subgroup of autistic females. Moreover, our method did not test for mutations in introns, promotor region, 5'UTR and 3'UTR.

The high prevalence of autism in males has focused the attention of researchers on $\mathrm{X}$ chromosome for a long time. Indeed, two genetic studies have highlighted a possible susceptibility region in Xq23. ${ }^{9,14}$ On the other hand, a number of full genome screen studies did not find significant increased allele sharing in the Xq28 region. ${ }^{15-17}$ These data, together with our results, make it very unlikely that MECP2 coding region mutations play a significant role in autistic disorder.

Table 1 Conditions for PCR amplification of the MECP2 gene fragments and for DGGE

\begin{tabular}{|c|c|c|c|c|c|}
\hline Primer & Sequence of primer & $\begin{array}{l}\text { Length } \\
(b p)\end{array}$ & $\begin{array}{l}\mathrm{Tm} \\
\left({ }^{\circ} \mathrm{C}\right)\end{array}$ & $\begin{array}{l}\text { Gradient } \\
\text { (\%ds) }\end{array}$ & $\begin{array}{l}\text { Voltage } \\
(\mathrm{V})^{*}\end{array}$ \\
\hline $1 F$ & $5^{\prime}-\mathrm{p}-$ ta-tttctttgtttaggctcca-3' & 190 & 55 & $40-70$ & 300 \\
\hline $2.1 \mathrm{~F}$ & $5^{\prime}-\mathrm{P}-$ ta-gagcccgtgcagccatcagc-3' & 170 & 55 & $40-90$ & 250 \\
\hline $2.1 \mathrm{R}$ & $5^{\prime}-$ cgtgtccagccttcaggcag $-3^{\prime}$ & & & & \\
\hline $2.2 \mathrm{~F}$ & $5^{\prime}-$ atgtatgatgaccccaccct $-3^{\prime}$ & 150 & 48 & $25-65$ & 180 \\
\hline $2.2 \mathrm{R}$ & $5^{\prime}-\mathrm{P}-$ ta-ctgtagagataggagttgct $-3^{\prime}$ & & & & \\
\hline $2.3 \mathrm{~F}$ & $5^{\prime}$-gtgatacttacatacttgtt $-3^{\prime}$ & 200 & 55 & $20-70$ & 180 \\
\hline $2.3 R$ & $5^{\prime}-\mathrm{P}-$ ta-ggctcagcagagtggtgggc $-3^{\prime}$ & & & & \\
\hline $3.1 \mathrm{~F}$ & $5^{\prime}-\mathrm{P}-\mathrm{ta}-\mathrm{tg} \operatorname{tg} t \mathrm{ctt}$ ctgtttgtccc $-3^{\prime}$ & 182 & 58 & $30-80$ & 200 \\
\hline 3.1R & $5^{\prime}$-gatttgggcttcttaggtgg-3' & & & & \\
\hline $3.2 \mathrm{~F}$ & $5^{\prime}-\mathrm{P}-$ ta-cctcccggcgagagcagaaa-3' & 240 & 58 & $45-80$ & 240 \\
\hline $3.2 \mathrm{R}$ & $5^{\prime}-\operatorname{tgacctgggtggatgtggtg}-3^{\prime}$ & & & & \\
\hline $3.3 \mathrm{~F}$ & $5^{\prime}-$ tgcctttcaaacttcgcca-3' & 344 & 55 & $40-85$ & 380 \\
\hline $3.3 \mathrm{R}$ & $5^{\prime}-\mathrm{P}-\operatorname{ta}-\operatorname{tgaggaggcgctgctgctgc}-3^{\prime}$ & & & & \\
\hline $3.4 \mathrm{~F}$ & $5^{\prime}-$ gcagcagcagcgcctcctca-3' & 244 & 56 & $40-90$ & 300 \\
\hline $3.4 \mathrm{R}$ & $5^{\prime}-\mathrm{P}-$ ta-tggcaaccgcgggctgagtca-3' & & & & \\
\hline $3.5 \mathrm{~F}$ & $5^{\prime}-\mathrm{P}-$ ta-tgccccaaggagccagctaa-3' & 200 & 55 & $40-80$ & 240 \\
\hline $3.5 \mathrm{R}$ & $5^{\prime}-$ gctttgcaatccgctccgtg-3' & & & & \\
\hline
\end{tabular}

P: Psoralen; ds: denaturing solution; *: running conditions during $5 \mathrm{~h}$. 


\section{Acknowledgments}

We thank Professor C Moraine (INSERM U 316, Tours) for helpful discussion.

\section{References}

1 Lamb JA, Moore J, Bailey A, Monaco AP: Autism: recent molecular genetic advances. Hum Mol Genet 2000; 9: 861-868.

2 Hagberg B: Rett's Syndrome: prevalence and impact on progressive severe mental retardation in girls. Acta Paediatr Scand 1985; 74: 405-408.

3 Gillberg C: Autism and Rett syndrome: some notes on differential diagnosis. Am J Med Genet 1986; 24: 127-131.

4 Amir RE, Van den Veyver IB, Wan M, Tran CQ, Francke U, Zoghbi HY: Rett syndrome is caused by mutations in X-linked MECP2, encoding methyl-CpG-binding protein 2. Nature Genetics 1999; 23: $185-188$.

5 Bienvenu T, Carrié A, de Roux N et al: MECP2 mutations account for most cases of typical forms of Rett syndrome. Hum Mol Genet 2000; 9: $1377-1384$.

6 Huppke P, Laccone F, Krämer N, Engel W, Hanefeld F: Rett syndrome: analysis of MECP2 and clinical characterization of 31 patients. Hum Mol Genet 2000; 9: 1369-1375.

7 D'Esposito M, Quaderi NA, Ciccodicola A et al: Isolation, physical mapping, and northern analysis of the X-linked human gene encoding methyl CpG-binding protein, MECP2. Mamm Genome 1996; 7: $533-535$.

8 Meloni I, Bruttini M, Longo I et al: A mutation in the Rett syndrome gene, MECP2, causes X-linked mental retardation and progressive spasticity in males. Am J Hum Genet 2000; 67: $982-985$.
9 Petit E, Hérault J, Raynaud $\mathrm{M}$ et al: X chromosome and infantile autism. Biol Psychiatry 1996; 40: 457-464.

$10 \mathrm{Fu} \mathrm{YH}$, Kuhl DPA, Pizzuti A et al: Variation of the CGG repeat at the fragile $X$ site results in genetic instability: resolution of the Sherman paradox. Cell 1991; 67: 1047-1058.

11 Oberlé I, Rousseau F, Heitz D et al: Instability of a 550-base pair DNA segment and abnormal methylation in fragile $\mathrm{X}$ syndrome. Science 1991; 252: 1097-1102.

12 Puy H, Deybach JC, Lamoril J et al: Molecular epidemiology and diagnosis of PBG deaminase gene defects in acute intermittent porphyria. Am J Hum Genet 1997; 60: 1373-1383.

13 Buyse IM, Fang P, Hoon KT, Amir RE, Zoghbi HY, Roa BB: Diagnostic testing for Rett syndrome by DHPLC and direct sequencing analysis of the MECP2 gene: identification of several novel mutations and polymorphisms. Am J Hum Genet 2000; 67: $1428-1436$.

14 Hallmayer J, Hebert JM, Spiker D et al: Autism and the X chromosome. Arch Gen Psychiatry 1996; 53: 985 - 989.

15 Risch N, Spiker D, Lotspeich L et al: A genomic screen of autism: Evidence for a multilocus etiology. Am J Hum Genet 1999; 65: $493-507$.

16 Philippe A, Martinez M, Guilloud-Batialle M et al: Genome-wide scan for autism susceptibility genes. Hum Mol Genet 1999; 8 : $805-812$.

17 International Molecular Genetic Study of Autism Consortium. A full genome screen for autism with evidence for linkage to a region on chromosome 7q. Hum Mol Genet 1998; 7: 571-578. 